\title{
Rev Saude Publica. 2013;47(3):603
}

Figura 1.| Figure 1.

A figura correta é a que segue: | Please find below the correct figure:

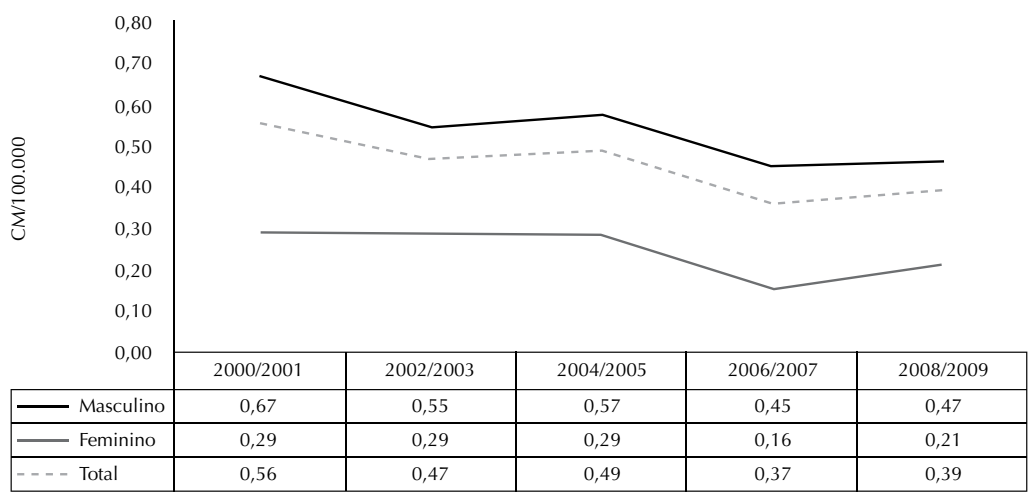

Fonte: Ministério da Saúde. Sistema de Informações sobre Mortalidade, 2000-2009, Pesquisa Nacional por Amostra de Domicílio (PNAD)/ Instituto Brasileiro de Geografia e Estatística (IBGE) 2000-2009.

Figura 1. Coeficiente de mortalidade por acidentes de trabalho por intoxicações por agrotóxicos $(\mathrm{CM} / 100.000)$ entre trabalhadores da agropecuária, por sexo e biênio. Brasil, 2000-2009. 